\title{
Dammarane-type saponins from steamed leaves of Panax notoginseng
}

\author{
Qing LiU, ${ }^{\mathrm{a}}$ Jun-Jiang Lv, ${ }^{\mathrm{a}, \mathrm{b}}$ Min Xu, ${ }^{\mathrm{a}}$ Dong WANG, ${ }^{\mathrm{a}}$ Hong-Tao ZHU, ${ }^{\mathrm{a}}$ Chong-Ren YANG, ${ }^{\mathrm{a}, \mathrm{c}}$ and Ying-Jun \\ ZHANG ${ }^{\mathrm{a}, *}$
}

${ }^{a}$ State Key Laboratory of Phytochemistry and Plant Resources in West China, Kunming Institute of Botany, Chinese Academy of Sciences, Kunming 650201, China

${ }^{\mathrm{b}}$ Graduate University of Chinese Academy of Sciences, Beijing 100049, China

${ }^{\mathrm{c}}$ Weihe Biotech Research and Development Center, Yuxi 653101, China

Received 22 November 2011; Accepted 11 December 2011

(C) The Author(s) 2011. This article is published with open access at Springerlink.com

\begin{abstract}
Four new dammarane-type triterpenoid saponins, namely notoginsenosides $\mathrm{SFt}_{1}-\mathrm{SFt}_{4}(\mathbf{1}-\mathbf{4})$ were isolated from the steamed leaves of Panax notoginseng (Burk.) F. H. Chen (Araliaceae), together with 17 known saponins. Their structures were established on the basis of detailed spectroscopic analyses and acidic hydrolysis. The known ginsenosides $\mathrm{Rk}_{2}$ and $\mathrm{Rh}_{3}$ were obtained from $P$. notoginseng for the first time. All of these new saponins showed no in vitro cytotoxicity against five human cancer cell lines (HL-60, SMMC-7712, A-549, MCF-7, and SW480).
\end{abstract}

Keywords: Panax notoginseng, steamed leave, dammarane-type saponin, notoginsenoside

\section{Introduction}

Panax notoginseng (Burk.) F. H. Chen (Araliaceae), a famous traditional Chinese medicinal (TCM) herb, is mainly cultivated in Yunnan and Guangxi province of China. Both roots and leaves have been used medicinally by the local people of its growing area for a long time. ${ }^{1}$ Traditionally, the roots have been used in both raw and processed forms. The raw one has been mainly used for injuries from falls and removing blood stasis, while the processed one has been used as a tonic to promote blood circulation. ${ }^{2}$ The leaves had the similar effects on hematological and cardiovascular systems as the roots. Dammarane-type triterpenoid saponins are known to be the main bioactive constituents in $P$. notoginseng. So far, more than 70 saponins have been isolated from different organs of this herbs. ${ }^{3}$ Our previous study on the steamed roots of $P$. notoginseng resulted in the identification of five new and 23 known dammarane-type saponins, part of which are the minor constituents in non-processed roots. ${ }^{4}$ As part of our continuing search for new saponins from Panax plants, a detailed chemical investigation on the steamed leaves of $P$. notoginseng was carried out, which led to the isolation of four new dammarane-type triterpenoid saponins (1-4), along with 17 known ones. Their structures were established based on the detailed spectroscopic analyses and acidic hydrolysis. The new saponins 1-4 were tested for their cytotoxic activities against five human cancer cell lines (HL-60, SMMC-7712, A-549, MCF-7, and SW480) in vitro.

*To whom correspondence should be addressed. E-mail: zhangyj@mail.kib.ac.cn

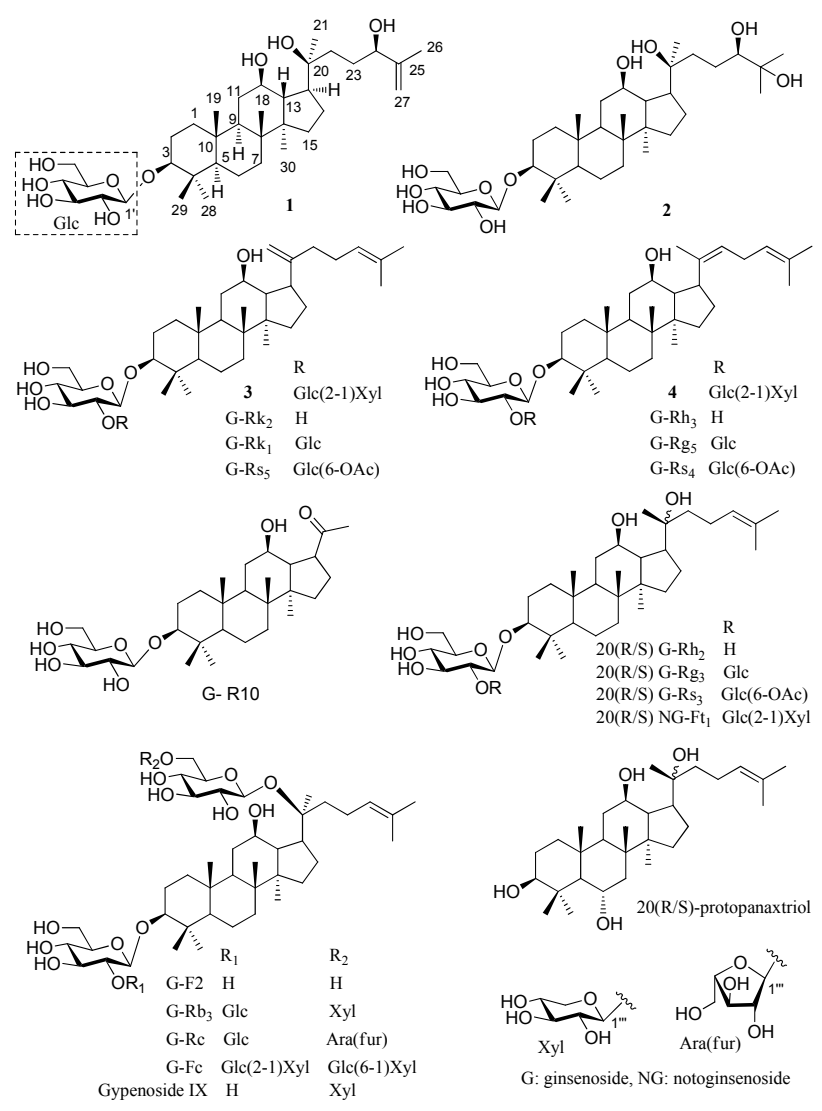


Table 1. ${ }^{1} \mathrm{H}$ NMR data $\left(500 \mathrm{MHz}, \mathrm{C}_{5} \mathrm{D}_{5} \mathrm{~N}\right)$ of compounds $1-4(\delta$ in ppm, $J$ in $\mathrm{Hz})$.

\begin{tabular}{|c|c|c|c|c|}
\hline No. & 1 & 2 & $3^{\mathrm{a}}$ & $4^{\mathrm{a}}$ \\
\hline 1 & $1.50 \mathrm{~m} ; 0.74$ br. s & $1.48 \mathrm{~m} ; 0.75$ br. s & $1.78 \mathrm{~m} ; 0.75 \mathrm{~m}$ & $1.74 \mathrm{~m} ; 0.74 \mathrm{~m}$ \\
\hline 2 & $1.90 \mathrm{~m} ; 1.47 \mathrm{~m}$ & $2.20 \mathrm{~m} ; 2.08 \mathrm{~m}$ & 2.18 br. d (11.6); $1.80 \mathrm{~m}$ & $2.18 \mathrm{dd}(13.5,3.0) ; 1.78 \mathrm{~m}$ \\
\hline 3 & $3.37 \mathrm{dd}(11.5,4.0)$ & $3.38 \mathrm{dd}(11.5,3.5)$ & $3.29 \mathrm{dd}(12.0,4.0)$ & $3.28 \mathrm{dd}(12.0,4.4)$ \\
\hline 5 & $0.72 \mathrm{t}(11.5)$ & $0.73 \mathrm{t}(11.5)$ & $0.68 \mathrm{t}(11.2)$ & $0.67 \mathrm{t}(11.2)$ \\
\hline 6 & $1.52 \mathrm{~m} ; 1.40 \mathrm{~m}$ & $1.48 \mathrm{~m} ; 1.34 \mathrm{~m}$ & $1.40 \mathrm{~m}$ & $1.47 \mathrm{~m} ; 1.04 \mathrm{~m}$ \\
\hline 7 & $1.48 \mathrm{~m} ; 1.20$ br. d (11.5) & $1.43 \mathrm{~m} ; 1.22$ br. d (11.0) & $1.46 \mathrm{~m} ; 1.38 \mathrm{~m}$ & $1.42 \mathrm{~m} ; 1.20$ br. d (10.5) \\
\hline 9 & $1.42 \mathrm{~m}$ & $1.40 \mathrm{~m}$ & $1.38 \mathrm{~m}$ & $1.39 \mathrm{~m}$ \\
\hline 11 & $2.17 \mathrm{~m} ; 1.39 \mathrm{~m}$ & $2.00 \mathrm{~m} ; 1.37 \mathrm{~m}$ & $2.05 \mathrm{~m}$ & $1.97 \mathrm{~m} ; 1.35 \mathrm{~m}$ \\
\hline 12 & $4.25 \mathrm{~m}$ & $4.25 \mathrm{~m}$ & $3.87 \mathrm{~m}$ & $3.91 \mathrm{~m}$ \\
\hline 13 & $2.12 \mathrm{~m}$ & $2.06 \mathrm{~m}$ & $3.68 \mathrm{~m}$ & $3.68 \mathrm{~m}$ \\
\hline 15 & $2.02 \mathrm{~m} ; 1.52 \mathrm{~m}$ & $1.56 \mathrm{~m} ; 1.02 \mathrm{~m}$ & $1.48 \mathrm{~m} ; 1.10 \mathrm{~m}$ & $1.50 \mathrm{~m} ; 1.04 \mathrm{~m}$ \\
\hline 16 & $2.22 \mathrm{~m} ; 1.81 \mathrm{~m}$ & $2.20 \mathrm{~m} ; 2.08 \mathrm{~m}$ & $2.05 \mathrm{~m} ; 1.56$ br. s & $1.97 \mathrm{~m} ; 1.48 \mathrm{~m}$ \\
\hline 17 & $2.37 \mathrm{~m}$ & $2.37 \mathrm{~m}$ & $2.79 \mathrm{~m}$ & $2.77 \mathrm{~m}$ \\
\hline 18 & $0.95 \mathrm{~s}$ & $0.94 \mathrm{~s}$ & $0.95 \mathrm{~s}$ & $0.94 \mathrm{~s}$ \\
\hline 19 & $0.78 \mathrm{~s}$ & $0.79 \mathrm{~s}$ & $0.78 \mathrm{~s}$ & $0.78 \mathrm{~s}$ \\
\hline 21 & $1.44 \mathrm{~s}$ & $1.46 \mathrm{~s}$ & $5.14 \mathrm{~s}$ & $1.81 \mathrm{~s}$ \\
\hline 22 & $2.04 \mathrm{~m} ; 1.54 \mathrm{~m}$ & $1.90 \mathrm{~m} ; 1.83 \mathrm{~m}$ & $2.46 \mathrm{~m} ; 2.29 \mathrm{~m}$ & $5.49 \mathrm{t}(6.8)$ \\
\hline 23 & $2.09 \mathrm{~m}$ & $2.53 \mathrm{~m} ; 1.80 \mathrm{~m}$ & $2.96 \mathrm{~m} ; 2.37 \mathrm{~m}$ & $2.77 \mathrm{~m}$ \\
\hline 24 & $4.41 \mathrm{~m}$ & $3.82 \mathrm{~d}(10.0)$ & $5.28 \mathrm{~m}$ & $5.21 \mathrm{t}(7.2)$ \\
\hline 26 & $1.88 \mathrm{~s}$ & $1.54 \mathrm{~s}$ & $1.64 \mathrm{~s}$ & $1.60 \mathrm{~s}$ \\
\hline 27 & $5.26 \mathrm{~s} ; 4.91 \mathrm{~s}$ & $1.51 \mathrm{~s}$ & $1.58 \mathrm{~s}$ & $1.56 \mathrm{~s}$ \\
\hline 28 & $1.31 \mathrm{~s}$ & $1.32 \mathrm{~s}$ & $1.28 \mathrm{~s}$ & $1.27 \mathrm{~s}$ \\
\hline 29 & $0.98 \mathrm{~s}$ & $1.00 \mathrm{~s}$ & $1.10 \mathrm{~s}$ & $1.09 \mathrm{~s}$ \\
\hline 30 & $0.95 \mathrm{~s}$ & $0.96 \mathrm{~s}$ & $0.99 \mathrm{~s}$ & $0.99 \mathrm{~s}$ \\
\hline $1^{\prime}$ & $4.96 \mathrm{~d}(7.8)$ & $4.97 \mathrm{~d}(7.7)$ & $4.94 \mathrm{~d}(7.6)$ & $4.93 \mathrm{~d}(7.7)$ \\
\hline $2^{\prime}$ & $4.02 \mathrm{~m}$ & $4.06 \mathrm{t}(8.5)$ & $4.09 \mathrm{~m}$ & $4.08 \mathrm{~m}$ \\
\hline $3^{\prime}$ & $4.01 \mathrm{~m}$ & $4.25 \mathrm{~m}$ & $4.37 \mathrm{~m}$ & $4.36 \mathrm{~m}$ \\
\hline $4^{\prime}$ & $3.93 \mathrm{~m}$ & $3.90 \mathrm{~m}$ & $4.13 \mathrm{~m}$ & $4.22 \mathrm{~m}$ \\
\hline $5^{\prime}$ & $4.25 \mathrm{~m}$ & $4.03 \mathrm{~m}$ & $4.28 \mathrm{~m}$ & $4.24 \mathrm{~m}$ \\
\hline $6^{\prime}$ & $4.60 \mathrm{dd}(11.5,5.0) ; 4.41 \mathrm{~m}$ & 4.61 br. d (11.5); $4.42 \mathrm{dd}(11.5,5.0)$ & 4.58 br. d (11.6); $3.97 \mathrm{~m}$ & 4.57 br. d (10.0); $4.34 \mathrm{~m}$ \\
\hline $1 "$ & & & $5.53 \mathrm{~d}(7.6)$ & $5.52 \mathrm{~d}(7.7)$ \\
\hline $2^{\prime \prime}$ & & & $4.23 \mathrm{~m}$ & $4.20 \mathrm{~m}$ \\
\hline $3^{\prime \prime}$ & & & $4.34 \mathrm{~m}$ & $4.27 \mathrm{~m}$ \\
\hline $4 "$ & & & $4.13 \mathrm{~m}$ & $4.11 \mathrm{~m}$ \\
\hline $5^{\prime \prime}$ & & & $4.29 \mathrm{~m}$ & $4.35 \mathrm{~m}$ \\
\hline 6" & & & $4.48 \mathrm{dd}(11.0,1.8) ; 4.27 \mathrm{~m}$ & $4.47 \mathrm{dd}(11.2,2.4) ; 4.26 \mathrm{~m}$ \\
\hline 1"' & & & $5.42 \mathrm{~d}(6.5)$ & $5.41 \mathrm{~d}(6.5)$ \\
\hline $2^{\prime \prime \prime}$ & & & $4.09 \mathrm{~m}$ & $4.12 \mathrm{~m}$ \\
\hline 3"' & & & $4.36 \mathrm{~m}$ & $4.32 \mathrm{~m}$ \\
\hline $4 " '$ & & & $4.13 \mathrm{~m}$ & $4.14 \mathrm{~m}$ \\
\hline $5 " '$ & & & $3.97 \mathrm{~m}$ & $3.85 \mathrm{~m}$ \\
\hline
\end{tabular}

${ }^{\mathrm{a}}$ Recorded at $400 \mathrm{MHz}$.

\section{Results and Discussion}

After defatted by petroleum ether, the ethanolic extract of steamed leaves of $P$. notoginseng was subjected to column chromatography repeatedly over Diaion 101 resin, silica gel, MCI gel CHP 20P, RP-8, and RP-18, and preparative-HPLC to afford four new dammarane-type triterpenoid saponins, namely, notoginsenosides $\mathrm{SFt}_{1}-\mathrm{SFt}_{4}(\mathbf{1}-\mathbf{4})$, together with 17 known compounds.

The known compounds were identified as ginsenoside R10, ginsenosides $\mathrm{Rk}_{2},{ }^{6} \mathrm{Rh}_{3},{ }^{6} \mathrm{Rk}_{1},{ }^{6} \mathrm{Rg}_{5}{ }^{6}{ }^{6} \mathrm{Rs}_{5}{ }^{7}$ and $\mathrm{Rs}_{4},{ }^{7} 20(\mathrm{R} / \mathrm{S})$ ginsenosides $\mathrm{Rh}_{2},{ }^{8} \mathrm{Rg}_{3}{ }_{3}$ and $\mathrm{Rs}_{3},{ }_{10} \quad 20(\mathrm{R} / \mathrm{S})$-notoginsenoside $\mathrm{Ft}_{1},{ }^{11}$ ginsenosides $\mathrm{F}_{2},{ }^{8} \mathrm{Rb}_{3},{ }^{8} \mathrm{Rc}^{8}$ and $\mathrm{Fc},{ }^{12}$ gypenoside $\mathrm{IX}^{8}{ }^{8}$ and $20(R / S)$-protopanaxtriol, ${ }^{13}$ respectively, by comparison the spectroscopic and physical data with those previously reported values.

Compound 1 was a white amorphous powder. The molecular formula $\mathrm{C}_{36} \mathrm{H}_{62} \mathrm{O}_{9}$ was deduced from the HRESIMS data $(\mathrm{m} / \mathrm{z}$ 673.4067, $\left.[\mathrm{M}+\mathrm{Cl}]]^{-}\right)$. The ${ }^{1} \mathrm{H}$ and ${ }^{13} \mathrm{C}$ NMR spectroscopic data indicated the presence of a protopanaxdiol aglycone $\left[\delta_{\mathrm{C}} 26.8\right.$ $\left(\mathrm{CH}_{2}, \mathrm{C}-2\right), 88.8(\mathrm{CH}, \mathrm{C}-3)$ and $\left.18.5\left(\mathrm{CH}_{2}, \mathrm{C}-6\right)\right]^{13}$ and a hexosyl unit $\left[\delta_{\mathrm{H}} 4.96(1 \mathrm{H}, \mathrm{d}, J=7.8 \mathrm{~Hz}), \delta_{\mathrm{H}} 107.0\right.$ and 63.1$\left.]\right]$. Acidic hydrolysis of $\mathbf{1}$ gave D-glucose as the sole sugar moiety, which was determined to have a $\beta$ configuration on the basis of the large coupling constants of the anomeric proton $\left[\delta_{\mathrm{H}} 4.96\right.$ $(1 \mathrm{H}, \mathrm{d}, J=7.8 \mathrm{~Hz})]$. The aforementioned data demonstrated that compound 1 should be a protopanaxdiol triterpenoid saponin. Compared with protopanaxdiol, ${ }^{14}$ the aglycone of 1 possesses a terminal double bonds $\left[\delta_{\mathrm{H}} 5.26,4.91(\right.$ each $1 \mathrm{H}, \mathrm{s}), \delta_{\mathrm{H}}$ $109.9\left(\mathrm{CH}_{2}\right)$ and 150.0 (quaternary carbon)] and an oxygenatedmethine, instead of a methyl (C-27) and a methylene (C-24) in protopanaxdiol. The structure of $\mathbf{1}$ was further deduced by HMBC and HSQC experiments. The HMBC correlations (Figure 1) of $\delta_{\mathrm{H}} 2.09\left(\mathrm{~m}, \mathrm{CH}_{2}\right)$ with $\delta_{\mathrm{C}} 73.1(\mathrm{C}-20), \delta_{\mathrm{H}} 4.41(\mathrm{~m}$, oxygenated $\mathrm{CH})$ and $1.88\left(\mathrm{~s}, \mathrm{CH}_{3}\right)$ with $\delta_{\mathrm{C}} 109.9$ and 150.0 (terminal double bond), the glucosyl H-1' $\left(\delta_{\mathrm{H}} 4.96\right)$ with C-3 $\left(\delta_{\mathrm{C}} 88.8\right)$ of aglycone were observed. The configuration of the $\mathrm{C}-24$ was established to be $R$ by the comparison of the ${ }^{13} \mathrm{C}$ NMR data with those of the C-24 epimers of ginsenoside-

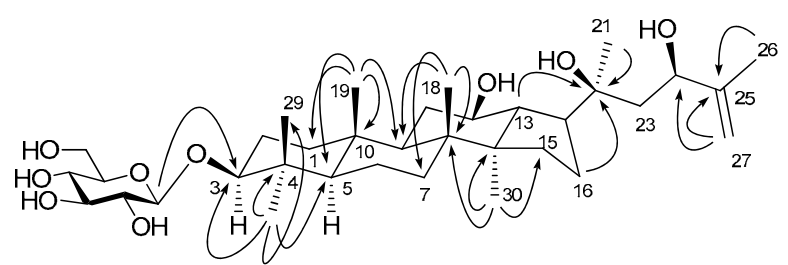

Figure 1. The key HMBC correlations $(\mathrm{H} \rightarrow \mathrm{C})$ of compound $\mathbf{1}$. 
Table 2. ${ }^{13} \mathrm{C}$ NMR data (125 MHz, $\left.\mathrm{C}_{5} \mathrm{D}_{5} \mathrm{~N}\right)$ of compounds $1-4(\delta$ in ppm).

\begin{tabular}{|c|c|c|c|c|c|c|c|c|c|}
\hline No. & 1 & 2 & $3^{\mathrm{a}}$ & $4^{a}$ & No. & 1 & 2 & $3^{\mathrm{a}}$ & $4^{a}$ \\
\hline 1 & $39.2\left(\mathrm{CH}_{2}\right)$ & $39.7\left(\mathrm{CH}_{2}\right)$ & $39.8\left(\mathrm{CH}_{2}\right)$ & $39.3\left(\mathrm{CH}_{2}\right)$ & 25 & $150.0(\mathrm{C})$ & $72.8(\mathrm{C})$ & $131.2(\mathrm{C})$ & $131.3(\mathrm{C})$ \\
\hline 2 & $26.8\left(\mathrm{CH}_{2}\right)$ & $26.8\left(\mathrm{CH}_{2}\right)$ & $26.8\left(\mathrm{CH}_{2}\right)$ & $28.8\left(\mathrm{CH}_{2}\right)$ & 26 & $18.5\left(\mathrm{CH}_{3}\right)$ & $26.2\left(\mathrm{CH}_{3}\right)$ & $25.8\left(\mathrm{CH}_{3}\right)$ & $25.8\left(\mathrm{CH}_{3}\right)$ \\
\hline 3 & $88.8(\mathrm{CH})$ & $88.8(\mathrm{CH})$ & $88.9(\mathrm{CH})$ & $88.9(\mathrm{CH})$ & 27 & $109.9\left(\mathrm{CH}_{2}\right)$ & $26.0\left(\mathrm{CH}_{3}\right)$ & $17.8\left(\mathrm{CH}_{3}\right)$ & $17.8\left(\mathrm{CH}_{3}\right)$ \\
\hline 4 & $39.7(\mathrm{C})$ & $39.2(\mathrm{C})$ & $39.3(\mathrm{C})$ & $40.3(\mathrm{C})$ & 28 & $28.2\left(\mathrm{CH}_{3}\right)$ & $28.2\left(\mathrm{CH}_{3}\right)$ & $28.1\left(\mathrm{CH}_{3}\right)$ & $28.1\left(\mathrm{CH}_{3}\right)$ \\
\hline 5 & $56.4(\mathrm{CH})$ & $56.4(\mathrm{CH})$ & $56.4(\mathrm{CH})$ & $56.4(\mathrm{CH})$ & 29 & $15.9\left(\mathrm{CH}_{3}\right)$ & $15.8\left(\mathrm{CH}_{3}\right)$ & $16.7\left(\mathrm{CH}_{3}\right)$ & $15.8\left(\mathrm{CH}_{3}\right)$ \\
\hline 6 & $18.5\left(\mathrm{CH}_{2}\right)$ & $18.5\left(\mathrm{CH}_{2}\right)$ & $18.5\left(\mathrm{CH}_{2}\right)$ & $18.5\left(\mathrm{CH}_{2}\right)$ & 30 & $17.1\left(\mathrm{CH}_{3}\right)$ & $17.1\left(\mathrm{CH}_{3}\right)$ & $17.0\left(\mathrm{CH}_{3}\right)$ & $17.1\left(\mathrm{CH}_{3}\right)$ \\
\hline 7 & $35.2\left(\mathrm{CH}_{2}\right)$ & $35.2\left(\mathrm{CH}_{2}\right)$ & $35.2\left(\mathrm{CH}_{2}\right)$ & $35.4\left(\mathrm{CH}_{2}\right)$ & $1^{\prime}$ & $107.0(\mathrm{CH})$ & $107.0(\mathrm{CH})$ & $104.8(\mathrm{CH})$ & $104.9(\mathrm{CH})$ \\
\hline 8 & $40.0(\mathrm{C})$ & $40.0(\mathrm{C})$ & $40.2(\mathrm{C})$ & $39.8(\mathrm{C})$ & $2^{\prime}$ & $75.8(\mathrm{CH})$ & $75.8(\mathrm{CH})$ & $83.0(\mathrm{CH})$ & $83.0(\mathrm{CH})$ \\
\hline 9 & $50.4(\mathrm{CH})$ & $50.5(\mathrm{CH})$ & $48.2(\mathrm{CH})$ & $50.9(\mathrm{CH})$ & $3^{\prime}$ & $78.8(\mathrm{CH})$ & $78.8(\mathrm{CH})$ & $78.7(\mathrm{CH})$ & $78.7(\mathrm{CH})$ \\
\hline 10 & $37.0(\mathrm{CH})$ & $37.0(\mathrm{CH})$ & $37.0(\mathrm{CH})$ & $37.1(\mathrm{CH})$ & $4^{\prime}$ & $71.0(\mathrm{CH})$ & $71.0(\mathrm{CH})$ & $71.1(\mathrm{CH})$ & $71.2(\mathrm{CH})$ \\
\hline 11 & $32.3\left(\mathrm{CH}_{2}\right)$ & $32.1\left(\mathrm{CH}_{2}\right)$ & $32.6\left(\mathrm{CH}_{2}\right)$ & $32.3\left(\mathrm{CH}_{2}\right)$ & $5^{\prime}$ & $78.4(\mathrm{CH})$ & $78.4(\mathrm{CH})$ & $78.3(\mathrm{CH})$ & $78.4(\mathrm{CH})$ \\
\hline 12 & $71.9(\mathrm{CH})$ & $71.9(\mathrm{CH})$ & $72.4(\mathrm{CH})$ & $72.6(\mathrm{CH})$ & $6^{\prime}$ & $63.1\left(\mathrm{CH}_{2}\right)$ & $63.1\left(\mathrm{CH}_{2}\right)$ & $63.0\left(\mathrm{CH}_{2}\right)$ & $63.0\left(\mathrm{CH}_{2}\right)$ \\
\hline 13 & $48.6(\mathrm{CH})$ & $48.6(\mathrm{CH})$ & $52.8(\mathrm{CH})$ & $50.8(\mathrm{CH})$ & $1 "$ & & & $103.2(\mathrm{CH})$ & $103.2(\mathrm{CH})$ \\
\hline 14 & $51.8(\mathrm{C})$ & $51.8(\mathrm{C})$ & $51.2(\mathrm{C})$ & $50.5(\mathrm{C})$ & $2 "$ & & & $84.6(\mathrm{CH})$ & $84.6(\mathrm{CH})$ \\
\hline 15 & $32.3\left(\mathrm{CH}_{2}\right)$ & $31.5\left(\mathrm{CH}_{2}\right)$ & $32.6\left(\mathrm{CH}_{2}\right)$ & $32.7\left(\mathrm{CH}_{2}\right)$ & $3 "$ & & & $78.0(\mathrm{CH})$ & $78.0(\mathrm{CH})$ \\
\hline 16 & $26.9\left(\mathrm{CH}_{2}\right)$ & $26.8\left(\mathrm{CH}_{2}\right)$ & $30.9\left(\mathrm{CH}_{2}\right)$ & $26.8\left(\mathrm{CH}_{2}\right)$ & 4" & & & $71.7(\mathrm{CH})$ & $71.8(\mathrm{CH})$ \\
\hline 17 & $54.9(\mathrm{CH})$ & $54.6(\mathrm{CH})$ & $50.8(\mathrm{CH})$ & $51.0(\mathrm{CH})$ & $5^{\prime \prime}$ & & & $77.9(\mathrm{CH})$ & $77.9(\mathrm{CH})$ \\
\hline 18 & $16.4\left(\mathrm{CH}_{3}\right)$ & $16.4\left(\mathrm{CH}_{3}\right)$ & $16.5\left(\mathrm{CH}_{3}\right)$ & $16.5\left(\mathrm{CH}_{3}\right)$ & 6" & & & $62.8\left(\mathrm{CH}_{2}\right)$ & $62.8\left(\mathrm{CH}_{2}\right)$ \\
\hline 19 & $16.8\left(\mathrm{CH}_{3}\right)$ & $16.8\left(\mathrm{CH}_{3}\right)$ & $15.8\left(\mathrm{CH}_{3}\right)$ & $16.7\left(\mathrm{CH}_{3}\right)$ & $1 " '$ & & & $106.5(\mathrm{CH})$ & $106.5(\mathrm{CH})$ \\
\hline 20 & $73.1(\mathrm{C})$ & $73.3(\mathrm{C})$ & $155.5(\mathrm{C})$ & $140.2(\mathrm{C})$ & $2^{\prime \prime \prime}$ & & & $76.0(\mathrm{CH})$ & $76.0(\mathrm{CH})$ \\
\hline 21 & $27.5\left(\mathrm{CH}_{3}\right)$ & $27.5\left(\mathrm{CH}_{3}\right)$ & $108.0\left(\mathrm{CH}_{2}\right)$ & $13.2\left(\mathrm{CH}_{3}\right)$ & 3"' & & & $77.8(\mathrm{CH})$ & $77.9(\mathrm{CH})$ \\
\hline 22 & $31.4\left(\mathrm{CH}_{2}\right)$ & $27.0\left(\mathrm{CH}_{2}\right)$ & $33.8\left(\mathrm{CH}_{2}\right)$ & $123.6(\mathrm{CH})$ & 4"' & & & $70.7(\mathrm{CH})$ & $70.8(\mathrm{CH})$ \\
\hline 23 & $30.7\left(\mathrm{CH}_{2}\right)$ & $33.9\left(\mathrm{CH}_{2}\right)$ & $27.1\left(\mathrm{CH}_{2}\right)$ & $27.5\left(\mathrm{CH}_{2}\right)$ & $5^{\prime \prime \prime}$ & & & $67.5\left(\mathrm{CH}_{2}\right)$ & $67.5\left(\mathrm{CH}_{2}\right)$ \\
\hline 24 & $76.1(\mathrm{CH})$ & $80.1(\mathrm{CH})$ & $125.4(\mathrm{CH})$ & $123.8(\mathrm{CH})$ & & & & & \\
\hline
\end{tabular}

${ }^{\mathrm{a}}$ Recorded at $100 \mathrm{MHz}$.

$\mathrm{Rg} 7{ }^{15}$ and majoroside-F2. ${ }^{16}$ The lower-field shifted ${ }^{13} \mathrm{C}$ NMR data of C-24 $\left(\delta_{\mathrm{C}} 76.1\right)$ and C-26 $\left(\delta_{\mathrm{C}} 109.9\right)$ [majoroside- $\mathrm{F}_{2}: \delta_{\mathrm{C}}$ $75.8(\mathrm{C}-24 S), 109.3$ (C-26); ginsenoside- $\mathrm{Rg}_{7}: \delta_{\mathrm{C}} 76.2(\mathrm{C}-24 R)$ ), 110.2 (C-26)] clearly confirmed the configuration of the C-24 hydroxyl group in $\mathbf{1}$. Accordingly, the structure of $\mathbf{1}$ was elucidated and named as notoginsenoside $\mathrm{SFt}_{1}$.

Compound 2, a white amorphous powder, had a molecular formula $\mathrm{C}_{36} \mathrm{H}_{64} \mathrm{O}_{10}$ on the basis of the HRESIMS $(\mathrm{m} / \mathrm{z}$ 691.4150, $\left.[\mathrm{M}+\mathrm{Cl}]^{-}\right)$. The ${ }^{1} \mathrm{H}$ and ${ }^{13} \mathrm{C}$ NMR spectroscopic data resembled that of $\mathbf{1}$, except for the loss of the double bond and the appearance of an additional oxygen-bearing quaternary carbon signal at $\delta_{\mathrm{C}} 72.8$. In the HMBC spectrum, the correlations of $\delta_{\mathrm{H}} 1.54,1.51$ (each $3 \mathrm{H}, \mathrm{s}, \mathrm{Me}-26$ and $\mathrm{Me}-27$ ) and 3.82 $(1 \mathrm{H}, \mathrm{d}, J=10.0 \mathrm{~Hz}$, oxygenated $\mathrm{CH})$ with $\delta_{\mathrm{C}} 72.8(\mathrm{C}-25)$, and $\delta_{\mathrm{H}} 3.82(1 \mathrm{H}, \mathrm{d}, J=10.0 \mathrm{~Hz}$, oxygenated $\mathrm{CH})$ with $\delta_{\mathrm{C}} 33.9(\mathrm{C}-$ $23)$ and 27.0 (C-22) were observed, which confirmed that the additional hydroxyl group should be linking to $\mathrm{C}-25$. The configuration of the C-24 (C-24: $\left.\delta_{\mathrm{C}} 80.1\right)$ was indicated to be $24 R$ on the comparison with the chemical shift values of cyclocantogenin $\left[\delta_{\mathrm{C}} 76.99(\mathrm{C}-24 S)\right]^{17}$ and tarecilioside A $\left[\delta_{\mathrm{C}}\right.$ $80.5(\mathrm{C}-24 R)]{ }^{18}$ Hence, the structure of compound 2 was established and named notoginsenoside $\mathrm{SFt}_{2}$.

Compound 3 had the molecular formula $\mathrm{C}_{47} \mathrm{H}_{78} \mathrm{O}_{16}$ based on the HRESI data $\left.(m / z \text { 897.5215, }[\mathrm{M}-\mathrm{H}]]^{-}\right)$. The ${ }^{1} \mathrm{H}$ and ${ }^{13} \mathrm{C}$ NMR data revealed that $\mathbf{3}$ was similar to the known dammarane saponin, ginsenoside $\mathrm{Rk}_{1},{ }^{6}$ except for an additional pentosyl unit. Acidic hydrolysis of $\mathbf{3}$ gave D-glucose and Dxylose as sugar residues. The large coupling constants of the anomeric protons $(J=7.6,7.6,6.5 \mathrm{~Hz})$ indicated the $\beta$ configurations of two glucosyl and one xylosyl moieties. Locations of the sugar moieties were established by the HMBC correlations of the inner glucosyl $\mathrm{H}-1^{\prime}\left(\delta_{\mathrm{H}} 4.94\right)$, the middle glucosyl $\mathrm{H}-1 "\left(\delta_{\mathrm{C}} 5.53\right)$, and the xylosyl H-1"' $\left(\delta_{\mathrm{H}} 5.42\right)$ with C-3 $\left(\delta_{\mathrm{C}}\right.$ $88.9)$, the inner glucosyl C-2' $\left(\delta_{\mathrm{C}} 83.0\right)$ and the middle glucosyl C-2" $\left(\delta_{\mathrm{C}} 84.6\right)$, respectively. Accordingly, the structure of compound $\mathbf{3}$ was established and named as notoginsenoside $\mathrm{SFt}_{3}$.

The molecular formula of compound $\mathbf{4}$ was deduced as $\mathrm{C}_{47} \mathrm{H}_{78} \mathrm{O}_{16}$ by the HRESIMS $\left(\mathrm{m} / z\right.$ 897.5235, $\left.[\mathrm{M}-\mathrm{H}]^{-}\right)$. The ${ }^{1} \mathrm{H}$ and ${ }^{13} \mathrm{C}$ NMR features of $\mathbf{4}$ were closely related to those of $\mathbf{3}$, including the same trisaccharide moiety. The only difference was that the terminal double bonds between C-20 and C-21 in 3 were changed to be a middle double bond between C-20 and $\mathrm{C}-22$ in 4 . This could be determined by comparison of the ${ }^{13} \mathrm{C}$ NMR data with those of the known compound ginsenoside $\mathrm{Rg}_{5}$ and further confirmed by HMBC correlations of $\delta_{\mathrm{H}} 1.81(\mathrm{Me}$, $\mathrm{C}-21)$ with $\delta_{\mathrm{C}} 51.0(\mathrm{C}-17), 140.2(\mathrm{C}-20)$ and $123.6(\mathrm{C}-22)$. Therefore, the structure of compound 5 was deduced and named as notoginsenoside $\mathrm{SFt}_{4}$.

Compounds 1-4 were tested for their cytotoxic activity against five human cancer cell lines, HL-60 myeloid leukemia, SMMC-7721 hepatocellular carcinoma, A-549 lung cancer, MCF-7 breast cancer, and SW480 colon cancer, applying the MTT method. However, none of them exhibited cytotoxicity at a concentration of $40 \mu \mathrm{M}$.

The present study indicated that the chemical constituents of the steamed leaves of $P$. notoginseng were significantly different from the un-processed ones. ${ }^{8}$ After steamed, a mass of low-pole triterpenoid saponins came forth. Being similar with the roots, the processed and the air-dried leaves must have different pharmacological activities and quality standard.

\section{Experimental Section}

General Experimental Procedures. Optical rotations were performed on a P-1020 polarimeter (JASCO, Tokyo, Japan). IR spectra were measured on a Bruker Tensor 27 spectrometer with $\mathrm{KBr}$ pellets. 1D and 2D NMR spectra were run on Bruker AM-400 and DRX-500 instruments operating at 400 and 500 $\mathrm{MHz}$ for ${ }^{1} \mathrm{H}$, and 100 and $125 \mathrm{MHz}$ for ${ }^{13} \mathrm{C}$, respectively. Coupling constants are expressed in Hertz and chemical shifts

\section{算 Springer}


are given on a ppm scale with tetramethylsilane as internal standard. The MS data were recorded on a VG Auto Spec-3000 spectrometer (VG, Manchester, U.K.) with glycerol as the matrix. HRESIMS were recorded on an API Qstar Pulsa LC/TOF spectrometer. GC analysis was run on a Shimadzu GC-14C gas chromatograph.

Column chromatography was performed with Diaion 101 resin (Tianjin Haiguang Chemical Co., Ltd. Tianjin, China), silica gel (200-300 mesh, Qingdao Makall Group Co., Ltd. Qingdao, China), MCI gel CHP 20P (Mitsubishi Chemical Co. Tokyo, Japan), Rp-8 gel, Rp-18 gel (40-60 $\mu \mathrm{m}$, Merck, Darmstadt, Germany) and a $250 \times 9.4 \mathrm{~mm}$, i.d., $5 \mu \mathrm{m}$ Zorbax SB-C ${ }_{18}$ column (Agilent, California, USA). Thin-layer chromatography (TLC) was carried out on silica gel $\mathrm{H}$-precoated plates (Qingdao Makall Group Co., Ltd.) with $\mathrm{CHCl}_{3} / \mathrm{MeOH} / \mathrm{H}_{2} \mathrm{O}$ $(8.5: 1.5: 0.1,8: 2: 0.2$ or 7:3:0.5, v/v), RP-8 and RP-18 precoated plates (Merck) with $\mathrm{MeOH} / \mathrm{H}_{2} \mathrm{O}(7: 3$ or $8: 2, \mathrm{v} / \mathrm{v})$. Spots were detected by spraying with $10 \% \mathrm{H}_{2} \mathrm{SO}_{4}$ in $\mathrm{EtOH}$ followed by heating.

Plant Material. Air-dried leaves of $P$. notoginseng were collected from Wenshan County, Yunnan province, China, in May, 2008. The raw leaves were mixed with appropriate amount of water and steamed at $120^{\circ} \mathrm{C}$ for $12 \mathrm{~h}$, to give steamed leaves.

Extraction and Isolation. The steamed leaves of $P$. notoginseng $(10 \mathrm{~kg})$ were extracted with ethanol for three times $(1.5 \mathrm{~h} \times 3)$ under reflux. The ethanolic extract was concentrated under reduced pressure to small volume, and then defatted with petroleum ether for 5 times. After removal of the organic solvent, the defatted ethanolic extract was subjected to a Diaion 101 resin column, eluting with $\mathrm{H}_{2} \mathrm{O}$ and $\mathrm{EtOH}$, successively. The EtOH elutes were combined and concentratedunder reduced pressure to give the total saponin fraction $(850 \mathrm{~g}), 200 \mathrm{~g}$ of which was subjected to silica gel column chromatography $(\mathrm{CC})(55 \times 6.2 \mathrm{~cm})$ eluted with $\mathrm{CHCl}_{3} / \mathrm{MeOH}(95: 5, \mathrm{v} / \mathrm{v})$ and $\mathrm{CHCl}_{3} / \mathrm{MeOH} / \mathrm{H}_{2} \mathrm{O}(9: 1: 0.1$ to 5:5:1, v/v) to afford 6 fractions (Fr. 1-6). Fr. 1 (12 g) was chromatographed over silica gel $\left(\mathrm{CHCl}_{3} / \mathrm{MeOH}, 95: 5\right.$ and 90:10, v/v), Rp-8 gel $\left(\mathrm{MeOH} / \mathrm{H}_{2} \mathrm{O}, 6: 4-9: 1, \mathrm{v} / \mathrm{v}\right)$, and $\mathrm{MCI}$ gel CHP 20P $\left(\mathrm{MeOH} / \mathrm{H}_{2} \mathrm{O}, 7: 3-1: 0, \mathrm{v} / \mathrm{v}\right)$ to afford $20(R / S)$ protopanaxtriol $(138 \mathrm{mg})$. Fr. $2(25 \mathrm{~g})$ was subjected to column chromatography on silica gel $\left(\mathrm{CHCl}_{3} / \mathrm{MeOH} / \mathrm{H}_{2} \mathrm{O}\right.$, 95:5:0, 9:1:0.1, 8.5:1.5:0.1 and 8:2:0.2, v/v), Rp-8 gel $\left(\mathrm{MeOH} / \mathrm{H}_{2} \mathrm{O}\right.$, 6:4-9:1, v/v), and pre-HPLC $\left(\mathrm{MeOH} / \mathrm{H}_{2} \mathrm{O}\right.$, $89: 11, \mathrm{v} / \mathrm{v})$ to give ginsenoside $\mathrm{R} 10(12 \mathrm{mg}), \mathrm{Rk}_{2}(11 \mathrm{mg}), \mathrm{Rh}_{3}$ $(7 \mathrm{mg})$ and $\mathrm{Rh}_{2}(1.1 \mathrm{~g})$. In a similar way, compounds 1 (140 $\mathrm{mg}), 2$ (11 mg), 3 (9 mg), 4 (15 mg), Rk $(4 \mathrm{mg}), \mathrm{Rg}_{5}$ (9 mg), $\mathrm{Rs}_{5}(8 \mathrm{mg}), \mathrm{Rs}_{4}(6 \mathrm{mg}), \mathrm{Rg}_{3}(206 \mathrm{mg}), \mathrm{Rs}_{3}(42 \mathrm{mg}), \mathrm{Ft}_{1}(51 \mathrm{mg})$ and $\mathrm{F}_{2}(8 \mathrm{mg})$ were obtained from Fr. $3(31 \mathrm{~g})$ and Fr. $4(11 \mathrm{~g})$, respectively. Each 1 gram sample of Fr. 5 (41 g) and Fr. 6 (36 g), respectively, was separated by Chromatorex ODS $\left(\mathrm{H}_{2} \mathrm{O} / \mathrm{MeOH} 1: 1, \mathrm{v} / \mathrm{v}\right)$, silica gel $\left(\mathrm{CHCl}_{3} / \mathrm{MeOH} / \mathrm{H}_{2} \mathrm{O}\right.$ 8:2:0.27:3:0.5) and Rp-8 gel $\left(\mathrm{MeOH} / \mathrm{H}_{2} \mathrm{O}, 6: 4-9: 1, \mathrm{v} / \mathrm{v}\right)$ to obtain the known compounds, gypenoside IX (450 mg), and ginsenosides $\mathrm{Rb}_{3}(52 \mathrm{mg}), \mathrm{Rc}(48 \mathrm{mg})$ and $\mathrm{Fc}(158 \mathrm{mg})$.

Notoginsenoside $\mathbf{S F t}_{\mathbf{1}}(\mathbf{1})$ : white amorphous powder; $[\alpha]_{\mathrm{D}}^{24}$ +9.4 (c 0.20, MeOH); IR (KBr) $v_{\max } 3442,2947,1640,1078$, $1022 \mathrm{~cm}^{-1}$; ${ }^{1} \mathrm{H}$ and ${ }^{13} \mathrm{C}$ NMR data see Tables 1 and 2; FABMS $m / z 637[\mathrm{M}-\mathrm{H}]^{-}, 475[\mathrm{M}-162 \text { (glucosyl) - H] }]^{-}$; HRESIMS $m / z 673.4067[\mathrm{M}+\mathrm{Cl}]^{-}$(calcd. for $\mathrm{C}_{36} \mathrm{H}_{62} \mathrm{O}_{9} \mathrm{Cl}, 673.4082$ ).

Notoginsenoside $\mathbf{S F t}_{\mathbf{2}}$ (2): white amorphous powder; $[\alpha]_{\mathrm{D}}^{24}$ -3.1 (c 0.12, MeOH); IR (KBr) $v_{\max } 3425,2946,1640,1078$, $1021 \mathrm{~cm}^{-1} ;{ }^{1} \mathrm{H}$ and ${ }^{13} \mathrm{C}$ NMR data see Tables 1 and 2 ; FABMS $m / z 656[\mathrm{M}-\mathrm{H}]^{-}, 493[\mathrm{M}-162 \text { (glucosyl) - H] }]^{-}$; HRESIMS $m / z 691.4150[\mathrm{M}+\mathrm{Cl}]^{-}$(calcd. for $\mathrm{C}_{36} \mathrm{H}_{64} \mathrm{O}_{10} \mathrm{Cl}, 691.4188$ ).

Notoginsenoside $\mathrm{SFt}_{3}$ (3): white amorphous powder; $[\alpha]_{\mathrm{D}}^{24}$ -3.6 (c 0.28, MeOH); IR (KBr) $v_{\max } 3424,2943,1639,1076$, $1044 \mathrm{~cm}^{-1} ;{ }^{1} \mathrm{H}$ and ${ }^{13} \mathrm{C}$ NMR data see Tables 1 and 2; FABMS $m / z 897[\mathrm{M}-\mathrm{H}]^{-}, 765[\mathrm{M}-132(\mathrm{xyl})-\mathrm{H}]^{-}, 603[\mathrm{M}-132$ (xyl) - 162 (glucosyl) - H] ; HRESIMS $m / z$ 897.5215 [M $\mathrm{H}]^{-}$(calcd. for $\mathrm{C}_{47} \mathrm{H}_{77} \mathrm{O}_{16}, 897.5211$ ).

Notoginsenoside $\mathrm{SFt}_{4}$ (4): white amorphous powder; $[\alpha]_{\mathrm{D}}^{24}$ -7.2 (c 0.12, MeOH); IR (KBr) $v_{\max } 3443,2927,1640,1076$, $1044 \mathrm{~cm}^{-1} ;{ }^{1} \mathrm{H}$ and ${ }^{13} \mathrm{C}$ NMR data see Tables 1 and 2; FABMS $m / z 897[\mathrm{M}-\mathrm{H}]^{-}, 765[\mathrm{M}-132 \text { (xyl) - H] }]^{-}, 603[\mathrm{M}-132$ (xyl) - 162 (glucosyl) - H] ; HRESIMS $m / z$ 897.5235 [M $\mathrm{H}]^{-}$(calcd. for $\mathrm{C}_{47} \mathrm{H}_{77} \mathrm{O}_{16}, 897.5211$ ).

Acidic Hydrolysis of Compounds 1-4. Compounds 1-4 (each 3-5 $\mathrm{mg}$ ) were hydrolyzed with $2 \mathrm{M} \mathrm{HCl} /$ dioxane (1:1, 4 $\mathrm{mL}$ ) under reflux for $6 \mathrm{~h}$, respectively. The reaction mixture was extracted with $\mathrm{CHCl}_{3}$ for five times $(2 \mathrm{~mL} \times 5)$. The aqueous layer was neutralized with $2 \mathrm{M} \mathrm{NaOH}$ and then dried to give a monosaccharide mixture. After that, a solution of the sugar mixture in pyridine $(2 \mathrm{~mL})$ was added to L-cysteine methyl ester hydrochloride (about $1.5 \mathrm{mg}$ ) and kept at $60^{\circ} \mathrm{C}$ for $1 \mathrm{~h}$. Then trimethylsilylimidazole (about $1.5 \mathrm{~mL}$ ) was added to the reaction mixture in ice-water base and kept at $60^{\circ} \mathrm{C}$ for $30 \mathrm{~min}$. The mixture was subjected to $\mathrm{GC}$ analysis, run on a Shimadzu GC-14C gas chromatograph equipped with a $30 \mathrm{~m}$ $\times 0.32 \mathrm{~mm}$ i.d. 30QC2/AC-5 quartz capillary column and an $\mathrm{H}_{2}$ flame ionization detector with the following conditions: column temperature, $180-280^{\circ} \mathrm{C}$; programmed increase, $3{ }^{\circ} \mathrm{C} / \mathrm{min}$; carrier gas, $\mathrm{N}_{2}(1 \mathrm{~mL} / \mathrm{min})$; injector and detector temperature, $250^{\circ} \mathrm{C}$; injection volume, $4 \mu \mathrm{L}$; and split ratio, $1 / 50$. The configuration of the sugar moiety was determined by comparing the retention time with the derivatives of the authentic samples.

Cytotoxic Bioassay. Human myeloid leukemia HL-60, hepatocellular carcinoma SMMC-7721, lung cancer A-549, breast cancer MCF-7, and colon cancer SW480 cell lines were used in the cytotoxic assay. The assay was performed by means of MTT [3-(4,5-dimethylthiazol-2-yl)-2,5-diphenlytetrezolium bromide] (Sigma, St. Louis, USA) method ${ }^{19}$ in 96well microplates. All the cells were cultured in RMPI1640 or DMEM medium (Hyclone, USA), supplemented with $10 \%$ fetal bovine serum (Hyclone, USA) in $5 \% \mathrm{CO}_{2}$ at $37{ }^{\circ} \mathrm{C} .100$ $\mu \mathrm{L}$ suspension was added to each well to seed cells in 96-well microplates, in which the tested samples were added with varied concentrations. After 48 hours incubation, MTT solution $[5 \mathrm{mg} / \mathrm{mL}$ in phosphate buffered saline (PBS)] was added $(20 \mu \mathrm{L} /$ well), and the incubation continued for another $4 \mathrm{~h}$ to give the formazan product. In each well $100 \mu \mathrm{L} 20 \%$ 
SDS was added after $100 \mu \mathrm{L}$ medium was removed, and it was then incubated over night to make the formazan product dissolve completely. The absorbance of the solution was measured at $595 \mathrm{~nm}$ in Bio-Rad 680. Concentration of a compound inhibiting $50 \%$ of cell growth $\left(\mathrm{IC}_{50}\right)$ was calculated by the Reed and Muench method.

\section{Electronic Supplementary Material}

Supplementary material is available in the online version of this article at http://dx.doi.org/10.1007/s13659-011-0036-2 and is accessible for authorized users.

\section{Acknowledgments}

The authors are grateful to the members of the analytical group at State Key Laboratory of Phytochemistry and Plant Resources in West China, Kunming Institute of Botany, Chinese Academy of Sciences, for measuring all the spectroscopic data. This work was supported by the 973 Program of Ministry of Science and Technology of China (2011CB915503).

Open Access This article is distributed under the terms of the Creative Commons Attribution License which permits any use, distribution, and reproduction in any medium, provided the original author(s) and source are credited.

\section{References}

[1] Ye D. D. J. Changchun Univ. Tradit. Chin. Med. 2007. 23, 104105.

[2] Ye, D. J.; Zhang, S. C. Herbs from roots and rhizomes. Chinese Medicinal Herbs Preparation. People's Medical Publishing House: Peking, China, 1999; p 187.
[3] Zhang, J. T. Ren Shen Guan Bai Cao: The Chemistry, Metabolism and Biological Activities of Ginseng. Chemical Industry Press: Beijing, 2008; chapter 3, pp 34-44.

[4] Liao, P. Y.; Wang, D.; Zhang, Y. J.; Yang, C. R. J. Agric. Food Chem. 2008, 56, 1751-1756.

[5] Li, P. Y.; Liu, J. P.; Lu, D.; Liu, C. G.; Du, X. J.; Li, F. 2011 Chinese Patent No. CN 101948497A.

[6] Park, I. H.; Kim, N. Y.; Han, S. B.; Kim, J. M.; Kwon, S. W.; Kim, H. J.; Park, M. K.; Park, J. H. Arch. Pharm. Res. 2002, 25, $428-432$.

[7] Park, I. H.; Han, S. B.; Kim, J. M.; Piao, L. Z.; Kwon, S. W.; Kim, N. Y.; Kang, T. L.; Park, M. K.; Park, J. H. Arch. Pharm. Res. 2002, 25, 837-841.

[8] Li, H. Z.; Zhang, Y. J.; Yang, C. R. Nat. Prod. Res. Dev. 2006, 18, $549-554$.

[9] Teng, R. W.; Li, H. Z.; Wang, D. Z.; He, Y. N.; Yang, C. R. Chin. J. Magn. Reson. 2000, 17, 461-468.

[10] Baek, N. I.; Kim, J. M.; Park, J. H.; Ryu, J. H.; Kim, D. S.; Lee, Y. H.; Park, J. D.; Kim, S. I. Arch. Pharm. Res. 1997, 20, 280 282.

[11] Chen, J. T.; Li, H. Z.; Wang, D.; Zhang, Y. J.; Yang, C. R. Helv. Chim. Acta 2006, 89, 1442-1447.

[12] Yang, T. R.; Kasai, R.; Zhou, J.; Tanaka, O. Phytochemistry 1983, 22, 1473-1478.

[13] Yu, M.; Zhao, Y. Q. Chin. Trad. Herbal Drugs 2002, 33, 404405.

[14] Usami, Y.; Liu, Y. N.; Lin, A. S.; Shibano, M.; Akiyama, T.; Itokawa, H.; Morris-Natschke, S. L.; Bastow, K.; Kasai, R.; Lee, K. H. J. Nat. Prod. 2008, 71, 478-481.

[15] Dou, D. Q.; Chen, Y. J.; Liang, L. H.; Pang, F. G.; Shimizu, N.; Takeda, T. Chem. Pharm. Bull. 2001, 49, 442-446.

[16] Feng, S. B.; Wang, X. S.; Wang, D. Q.; Yang, C. R.; Zhou, J. Acta Bot. Yunnan. 1987, 9, 477-488.

[17] Kucherbaev, K. D.; Uteniyazov, K. K.; Saatov, Z.; Shashkov, A. S. Chem. Nat. Comp. 2002, 38, 447-449.

[18] Zhao, Z.; Matsunami, K.; Otsaka, H.; Shinzato, T.; Takeda, Y. Chem. Pharm. Bull. 2008, 56, 1153-1158.

[19] Mosmann, T. J. Immunol. Methods 1983, 65, 55-63. 